\title{
Additive Effects of Zinc Chloride on the Suppression of Hepatitis A Virus Replication by Interferon in Human Hepatoma Huh7 Cells
}

\author{
TATSUO KANDA ${ }^{1}$, REINA SASAKI ${ }^{1}$, RYOTA MASUZAKI ${ }^{1}$, HIROSHI TAKAHASHI ${ }^{1}$, \\ MARIKO FUJISAWA $^{1}$, NAOKI MATSUMOTO ${ }^{1}$, HIROAKI OKAMOTO $^{2}$ and MITSUHIKO MORIYAMA ${ }^{1}$ \\ ${ }^{1}$ Division of Gastroenterology and Hepatology, Department of Medicine, \\ Nihon University School of Medicine, Tokyo, Japan; \\ ${ }^{2}$ Division of Virology, Department of Infection and Immunity, \\ Jichi Medical University School of Medicine, Tochigi-ken, Japan
}

\begin{abstract}
Background/Aim: Hepatitis A virus (HAV) infection is still one of the serious health problems worldwide, despite the existence of effective vaccines for HAV. Zinc compounds have antiviral activities against various DNA and RNA viruses. Therefore, we investigated the effects of zinc compounds on the antiviral activity of interferon against HAV. Materials and Methods: The effects of zinc compounds with or without interferon on HAV genotype IIIA HA11-1299 replication were examined in human hepatoma Huh7 cells. Cell viability was examined by the MTS assay. Inflammasome associated gene expression was examined by real-time reverse transcription-polymerase chain reaction. Results: Both zinc sulfate and zinc chloride had an inhibitory effect on HAV replication. Zinc sulfate tended to enhance while zinc chloride significantly enhanced the anti-HAV effect induced by interferon-alpha-2a. Zinc chloride significantly up-regulated mitogen-activated protein kinase 12 (MAPK12) and downregulated 6 related genes [baculoviral IAP repeat containing 3 (BIRC3), interleukin 1 beta $(I L 1 B)$, proline-serine-threonine phosphatase interacting protein 1 (PSTPIP1), prostaglandinendoperoxide synthase 2 (PTGS2), PYD and CARD domain containing (PYCARD), and tumor necrosis factor (TNF)]. Conclusion: Zinc chloride inhibits HAV replication and has additive effects on the anti-HAV activities of interferon.
\end{abstract}

This article is freely accessible online.

Correspondence to: Tatsuo Kanda, MD, Ph.D., Associate Professor, Division of Gastroenterology and Hepatology, Department of Medicine, Nihon University School of Medicine, 30-1 Oyaguchikamicho, Itabashi-ku, Tokyo 173-8610, Japan. Tel: +81 339728111, Fax: +81 339568496, e-mail: kanda.tatsuo@nihon-u.ac.jp

Key Words: Antivirals, HAV, inflammasomes, interferon, zinc.
Hepatitis A virus (HAV) is a single-stranded, positive sense RNA virus of $\sim 7,600 \mathrm{nt}$ in length. HAV is transmitted through the fecal-oral route and usually causes self-limited acute hepatitis, however, it occasionally leads to acute liver failure, causing death or the requirement of liver transplantation (1). Higher seroprevalence of anti-HAV antibodies reflects poorer water sanitation and increased exposure during childhood in developing countries (2). Sexual contact among men who have sex with men (MSM), and blood transfusion are other known transmission routes $(3,4)$.

HAV infection is the leading cause of pediatric acute liver failure in Asian countries (5), although the use of the HAV vaccine can prevent symptomatic hepatitis A, acute liver failure is still caused by HAV infection, and liver transplantation is required in many cases (6). Therefore, antiHAV drugs should be developed.

Zinc is the second most abundant trace metal, after iron, in the human body (7). The global prevalence of zinc deficiency is $20 \%$, with the majority occurring in developing countries (8). Zinc deficiency is common in developing countries as well as in Japan, which is a developed country (7). We have previously demonstrated that zinc sulfate inhibits HAV replication and upregulates expression of glucose-regulated protein 78 (GRP78) (9).

In the human myelomonocytic lymphoma cell line U937, zinc chloride increased interferon- $\alpha / \beta$ receptor 2 mRNA levels by approximately $30 \%$, compared to the control levels (10). Zinc seems to directly inhibit picornaviral protease and have an inhibitory effect on its polyprotein processing (6). In the present study, we examined the effects of zinc compounds on HAV replication and whether zinc compounds could enhance the inhibitory effects of interferon on HAV replication. The effects of zinc chloride on the inflammasome associated signaling pathway in hepatocytes were also investigated. 


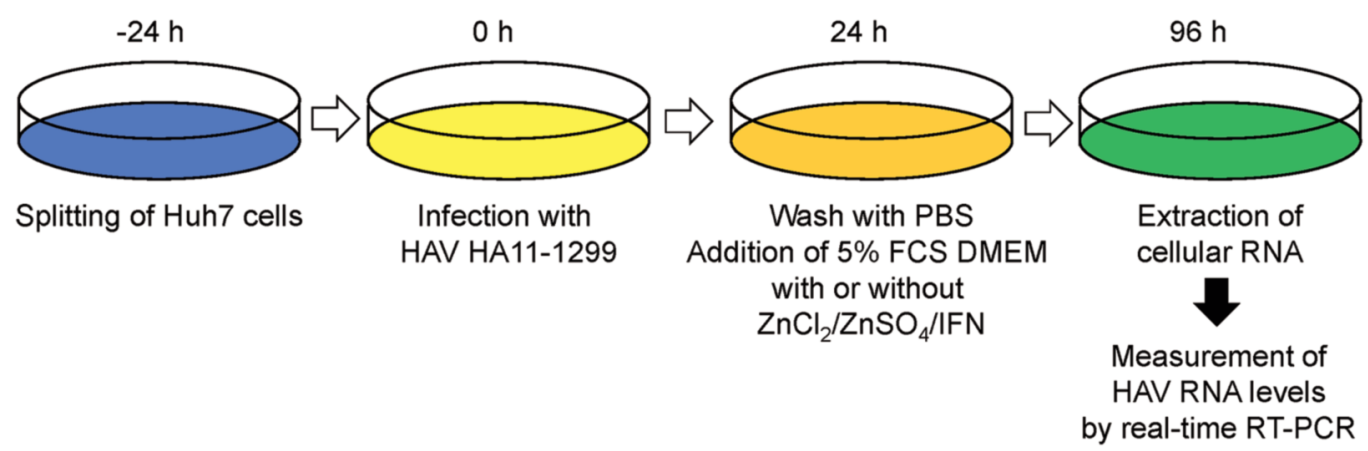

Figure 1. Illustration of the protocols for hepatitis A virus (HAV) infection, treatment with zinc compounds and cellular RNA extraction. PBS: Phosphate-buffered saline; FCS: fetal calf serum; DMEM: Dulbecco's Modified Eagle Medium; IFN: interferon.

\section{Materials and Methods}

Cells and virus. The human hepatoma cell lines Huh7 and HepG2 were maintained in Dulbecco's modified Eagle's medium (DMEM; Sigma-Aldrich, Saint Louis, MO, USA) containing $10 \%$ fetal calf serum (FCS), $100 \mathrm{U} / \mathrm{ml}$ penicillin $\mathrm{G}$ and $200 \mu \mathrm{g} / \mathrm{ml}$ streptomycin at $37^{\circ} \mathrm{C}$ in an atmosphere of $5 \% \mathrm{CO}_{2}(9)$. The HAV genotype IIIA HA11-1299 was established by Okamoto et al. and grown in cell culture as described previously (11).

HAV infection. Approximately $1.0 \times 10^{5}$ Huh7 cells were placed on 6-well tissue culture plates (Iwaki Glass, Tokyo, Japan) $24 \mathrm{~h}$ prior to infection. Huh7 cells were infected with 0.1 multiplicity of infection (MOI) or 0.01 MOI HAV genotype IIIA HA11-1299 after cells were washed with phosphate-buffered saline (PBS) twice. After $24 \mathrm{~h}$ of infection, cells were washed with PBS and maintained in 5\% FCS DMEM with or without zinc chloride (Wako Pure Chemical, Tokyo, Japan), zinc sulfate (Wako) and/or interferonalpha-2a (Sigma-Aldrich). After $96 \mathrm{~h}$ of infection, cellular RNA was extracted for the determination of HAV RNA (Figure 1).

Isolation of RNA and real-time reverse transcription (RT)-PCR. Total cellular RNA was extracted after HAV infection, using a RNeasy Mini kit (Qiagen, Hilden, North Rhine-Westphalia, Germany). To detect HAV genome sequences, RNA, oligo dT primers and random hexamers were used for cDNA synthesis using a PrimeScript RT reagent kit (Perfect Real Time; Takara BIO, Kusatsu, Shiga, Japan). HAV-specific RNA was quantitated by real-time PCR using a sense primer (5'-AGGCTACGGGTGAAACCTCTTAG-3') and an antisense primer (5'-GCCGCTGTTACCCTATCCAA-3') with Power SYBR Green Master Mix (Applied Biosystems, Foster City, CA, USA), following the manufacturer's protocol on a 7500 Fast real-time PCR system (Applied Biosystems). The housekeeping gene $\beta$-actin-specific RNA was also quantitated by real-time PCR using a sense primer (5'CAGCCATGTACGTTGCTATCCAGG-3') and an antisense primer (5'-AGGTCCAGACGCAGGATGGCATG-3'). Each real-time PCR assay was performed in triplicate. PCR reaction was performed as follows: $95^{\circ} \mathrm{C}$ for $10 \mathrm{~min}$, followed by 40 cycles at $95^{\circ} \mathrm{C}$ for $15 \mathrm{sec}$ and $60^{\circ} \mathrm{C}$ for $1 \mathrm{~min}$. These data were analyzed by the ddCt method.

MTS assay. Approximately $1.0 \times 10^{3}$ cells were plated on 96 well tissue culture plates (Iwaki Glass) with or without zinc chloride, zinc sulfate or interferon-alpha-2a. After 72 h, MTS assays were performed with the CellTiter 96 Aqueous One Solution Cell Proliferation Assay (Promega, Madison, WI, USA). In brief, $20 \mu 1$ MTS solution were added per well to $100 \mu$ l of media containing cells and left for $4 \mathrm{~h}$ at $37^{\circ} \mathrm{C}$ in an atmosphere of $5 \% \mathrm{CO}_{2}$. The absorbance at $490 \mathrm{~nm}$ was recorded using an iMark Microplate Absorbance Reader (Bio-Rad, Tokyo, Japan). Each assay was performed at least in triplicate.

Examination of the effects of zinc chloride on inflammasome associated signaling pathways in Huh7 cells infected with HAV. Human hepatoma Huh7 cells were infected with 0.1 MOI HAV genotype IIIA HA11-1299, and treated with or without $5 \mu \mathrm{M}$ zinc chloride at the same time. Medium with or without $5 \mu \mathrm{M}$ zinc chloride was exchanged on days 1, 3, 5. After $120 \mathrm{~h}$ of HAV infection and treatment with or without $5 \mu \mathrm{M}$ zinc chloride, cellular RNA was extracted using the RNeasy Mini kit (Qiagen), and cDNA synthesis was performed using RT2 First Strand kit (Qiagen), on a GeneAmp PCR system 5700 (Applied Biosystems).

Inflammasome associated signaling pathways were analyzed by an $\mathrm{RT}^{2}$ Profiler PCR array (Qiagen) on a 7500 Fast real-time PCR system (Applied Biosystems), according to the manufacturer's instruction. Data were analyzed by the RT ${ }^{2}$ Profiler PCR array Data Analysis software (Qiagen). Relative gene expression levels were normalized to housekeeping genes by ddCt method (12). We considered significant gene expression changes when the difference of gene expression was more than 2-fold and $p$-Value was less than 0.05 .

Statistical analysis. All data are shown as the mean \pm standard deviation. Statistical analysis was performed by Student's $t$-test. $p<0.05$ was considered as statistically significant.

\section{Results}

Zinc chloride inhibits HAV replication. To examine the cytotoxicity of zinc chloride and zinc sulfate, we performed MTS assays after $72 \mathrm{~h}$ of treatment of Huh7 or HepG2 cells with 0-20 $\mu \mathrm{M}$ zinc chloride or 0-20 $\mu \mathrm{M}$ zinc sulfate. Treatment with 5 or $10 \mu \mathrm{M}$ zinc chloride or zinc sulfate did not reduce the viability of human hepatoma cell lines (Figure 2).

Next, we compared the antiviral activities of zinc chloride, zinc sulfate and interferon-alpha-2a against HAV in Huh7 cells infected with 0.01 MOI HAV (Figures 1 and 3). 
A
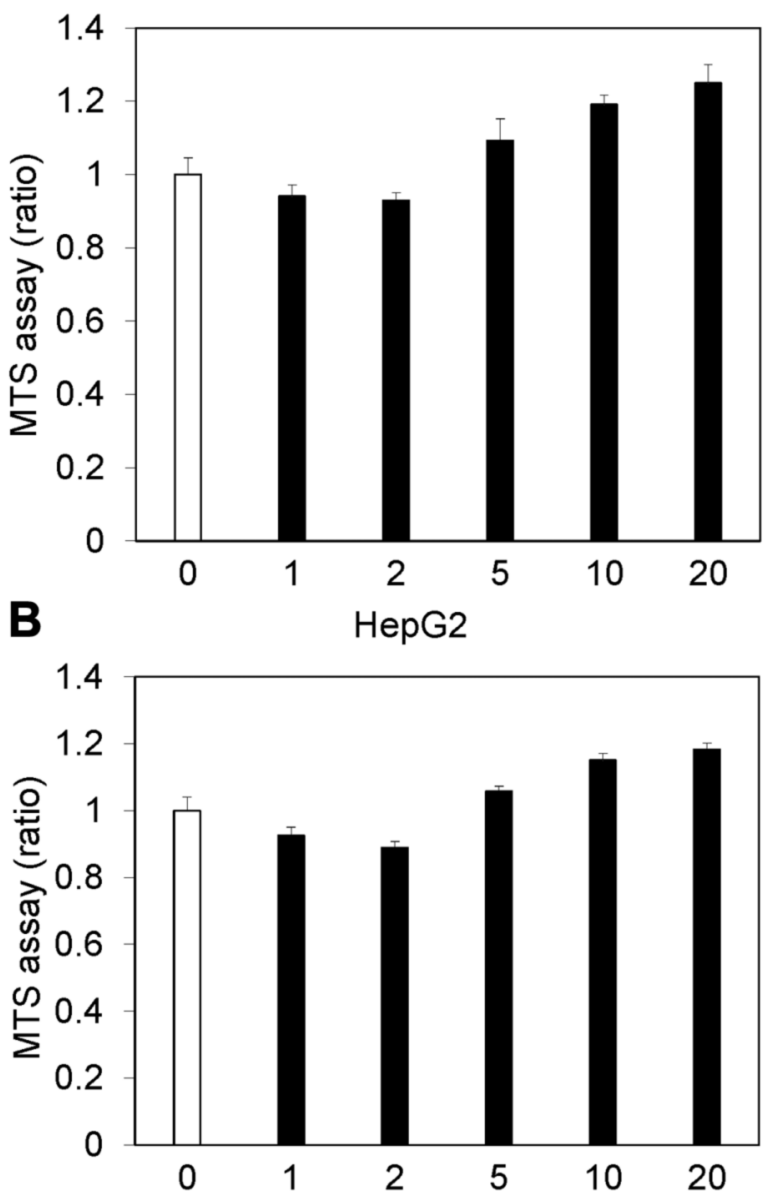

Huh7
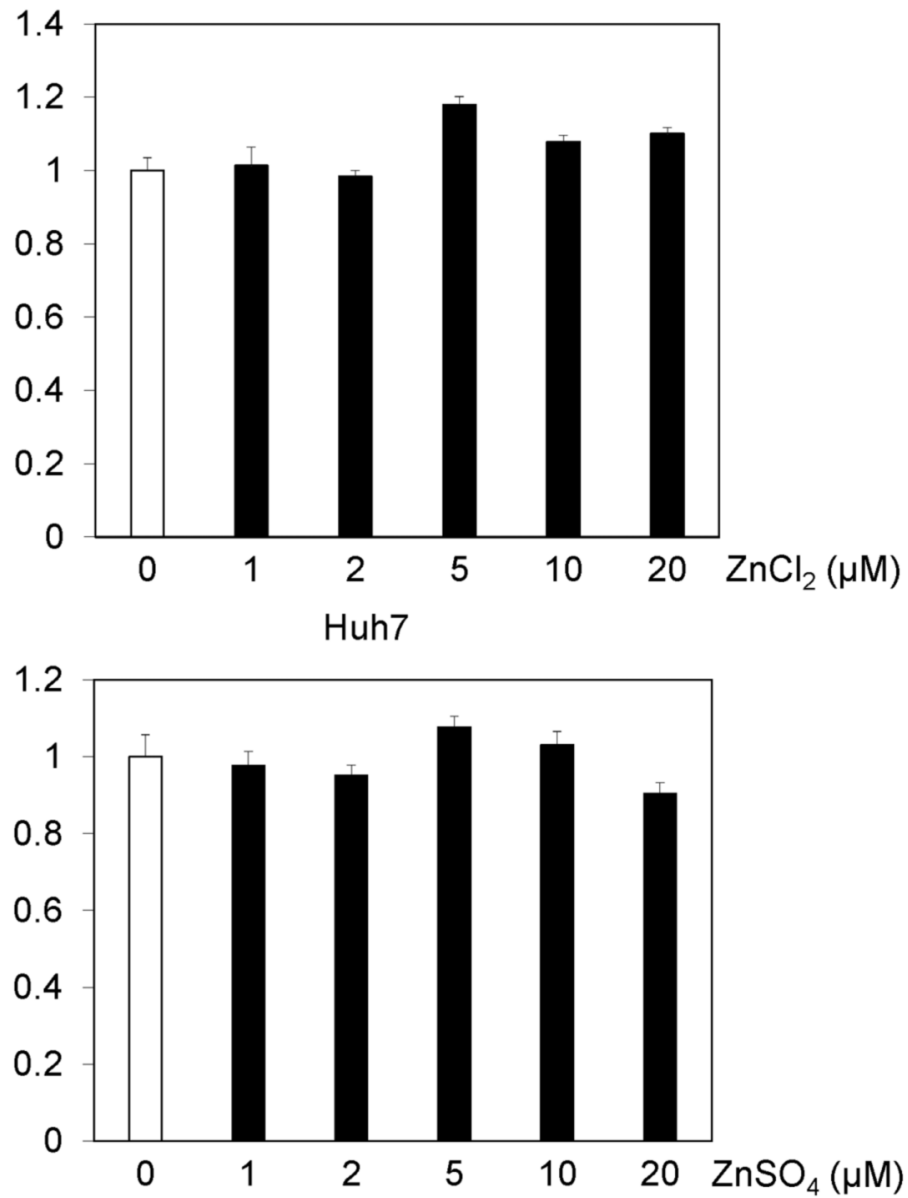

Figure 2. Effects of zinc compounds on the viability of human hepatocytes. The viability of HepG2 and Huh7 cells treated with zinc compounds for $72 \mathrm{~h}$. (A) Zinc chloride ( $\left.\mathrm{ZnCl}_{2}\right)$, (B) zinc sulfate $\left(\mathrm{ZnSO}_{4}\right)$. Cell viability was measured by MTS assay (see Materials and Methods section). Data are expressed as means \pm standard deviations of triplicate determinations from 3 independent experiments.

Seventy-two hours of treatment with $5 \mu \mathrm{M}$ zinc chloride suppressed HAV replication to $62.2 \%$ compared with the untreated control. Of note, we did not observe an inhibitory effect of $5 \mu \mathrm{M}$ zinc sulfate on HAV replication (at 136\%), although we have previously reported that $10 \mu \mathrm{M}$ zinc sulfate had an inhibitory effect on HAV replication (reduced to $32.2 \%$ ) (13). However, $72 \mathrm{~h}$ of treatment with 0.05 or 0.1 $\mu \mathrm{g} / \mathrm{ml}$ interferon-alpha-2a suppressed HAV replication to 25.1 or $14.8 \%$, respectively, compared with the untreated control. We determined that zinc chloride inhibits HAV replication.

Suppression of HAV replication was stronger with the combination of interferon plus zinc compounds than with interferon alone. As interferon has also an antiviral effect through the induction of interferon stimulated genes (ISG) and the degradation of RNA viruses (14), we evaluated the
anti-HAV activity of the combination of interferon plus zinc compounds (Figure 4). We infected Huh7 cells with 0.01 MOI HAV, and the drugs were added $24 \mathrm{~h}$ later. After $72 \mathrm{~h}$ of treatment with the drugs, cellular RNA was isolated, and HAV RNA levels were measured by real-time reverse transcription-polymerase chain reaction (RT-PCR).

Suppression of HAV replication was stronger with the combination of $0.05 \mu \mathrm{g} / \mathrm{ml}$ interferon-alpha-2a plus $5 \mu \mathrm{M}$ zinc chloride than with $0.05 \mu \mathrm{g} / \mathrm{ml}$ interferon-alpha-2a alone

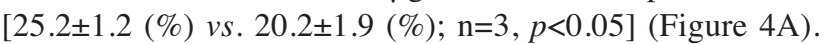
Suppression of HAV replication tended to be stronger with the combination of $0.05 \mu \mathrm{g} / \mathrm{ml}$ interferon-alpha-2a plus $5 \mu \mathrm{M}$ zinc sulfate than with $0.05 \mu \mathrm{g} / \mathrm{ml}$ interferon-alpha-2a alone

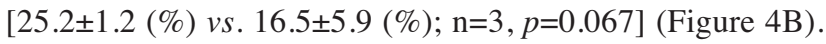
Thus, we demonstrated that zinc chloride could enhance the inhibitory effect of interferon on HAV replication. 


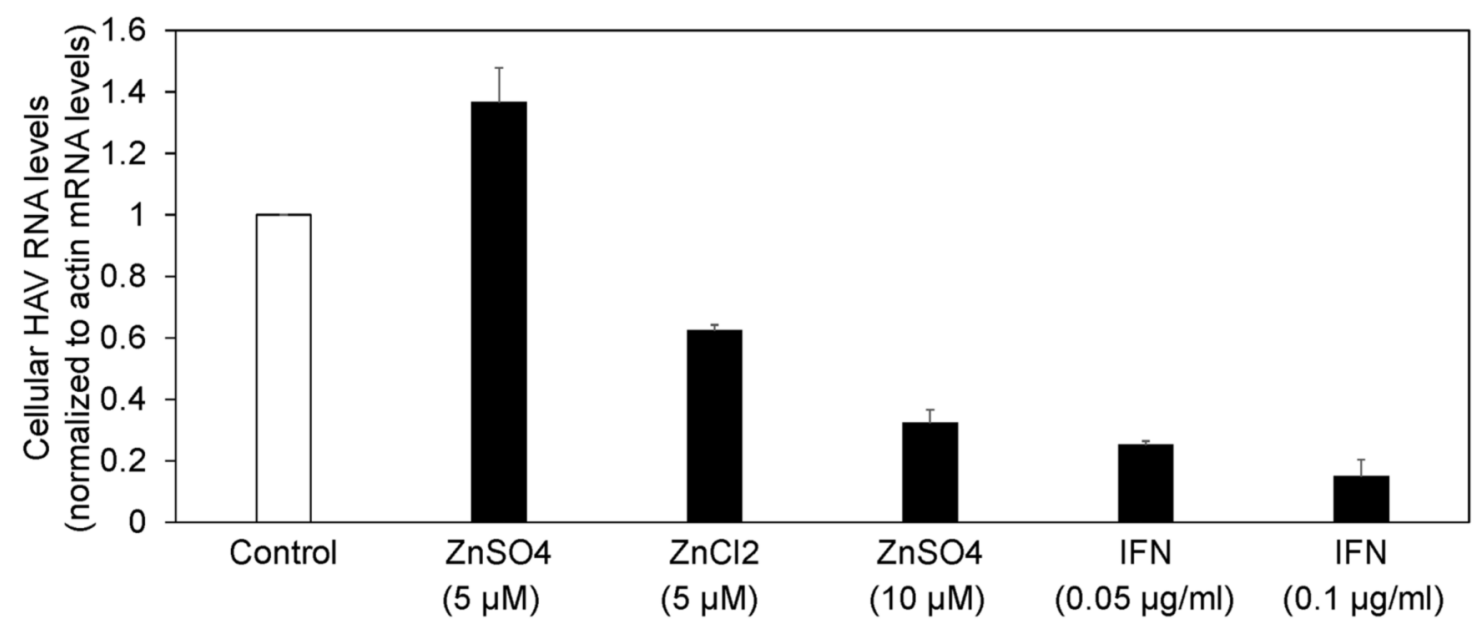

Figure 3. Zinc compounds and interferon inhibit hepatitis A virus (HAV) replication. Drugs were added 24 host infection with 0.01 MOI HAV genotype IIIA HA11-1299. HAV RNA was measured by real-time reverse transcription-polymerase chain reaction. IFN: Interferon. Data are expressed as means \pm standard deviations of triplicate determinations from 3 independent experiments.

Zinc chloride affects inflammasome associated signaling pathways in Huh7 cells infected with HAV. It has been reported that nucleotide organization domain (NOD)-like receptors (NLRs) can play a role in the host response to HAV infection $(15,16)$. Therefore, we examined the effects of $5 \mu \mathrm{M}$ zinc chloride on the replication of HAV genotype IIIA HA11-1299. We infected Huh7 cells with 0.1 MOI HAV and added $5 \mu \mathrm{M}$ zinc chloride at the same time. After $120 \mathrm{~h}$ of HAV infection and treatment with or without $5 \mu \mathrm{M}$ zinc chloride, cellular RNA was extracted, and HAV RNA was measured by real-time RT-PCR. HAV RNA levels were reduced to $75 \%$ in zinc chloride-treated Huh7 cells, compared with those in zinc chloride-untreated Huh7 cells.

It has recently been reported that chaperon-mediated autophagy (CMA) is involved in hepatic immunity and liver diseases, including acute-on-chronic liver failure (17-19). Therefore, we examined the effects of zinc chloride on human hepatic inflammasome associated signaling pathways. We collected total RNAs from HAV-infected Huh7 cells that were treated with or without zinc chloride to examine the influence of zinc chloride on human inflammasome associated pathways by using a real-time RT-PCR-based array. Among 84 genes that were examined, one and six genes, respectively, were significantly up-regulated and down-regulated (2-fold more) by zinc chloride in HAVinfected Huh7 cells (Figure 5 and Table I). Among them, tumor necrosis factor (TNF) and interleukin 1 beta (IL1B) were up-regulated in inflammatory cells of the liver after 3 weeks of HAV infection (20). HAV has been shown to upregulate TNF, leading to the induction of Th1 cytokines and cytotoxic $\mathrm{T}$ lymphocyte (CTL) response (21). TNF- producing regulatory $\mathrm{T}$ cells (Treg) have been associated with severe hepatitis A (22).

\section{Discussion}

In the present study, we demonstrated that both zinc sulfate and zinc chloride have an inhibitory effect on HAV replication. We also showed that zinc sulfate tended to enhance the anti-HAV effect induced by interferon-alpha-2a and that zinc chloride enhanced the anti-HAV effect induced by interferon-alpha-2a. Our results suggest that zinc chloride may affect the inflammasome associated signaling pathway in hepatocytes.

Activation of the interferon pathway promotes the transcriptional induction of many interferon-stimulated genes (ISGs), resulting in antiviral, anticancer and immunostimulatory status (23). Zinc chloride has been shown to up-regulate interferon alpha/beta receptor 2 mRNA levels (10), and to induce 2-5A synthetase (24). It has also been shown to regulate double-stranded RNA-activated protein kinase (PKR) (25) and to inhibit TNF-mediated apoptosis through heat shock protein 70 (26). We also demonstrated that zinc chloride inhibits the expression of TNF mRNA in Huh7 cells (Table I). Zinc chloride has also been shown to induce interferon-gamma-inducing factors (27). In the present study, zinc chloride induced interferon regulatory factor 2 (IRF2) (1.35-fold, $p=0.005459)$, compared with untreated Huh7 control. Thus, there may be an association between zinc chloride and activation of interferon signaling pathways.

Zinc compounds may have potential therapeutic effects on patients infected with picornaviruses, including $\operatorname{HAV}(9,28)$, 


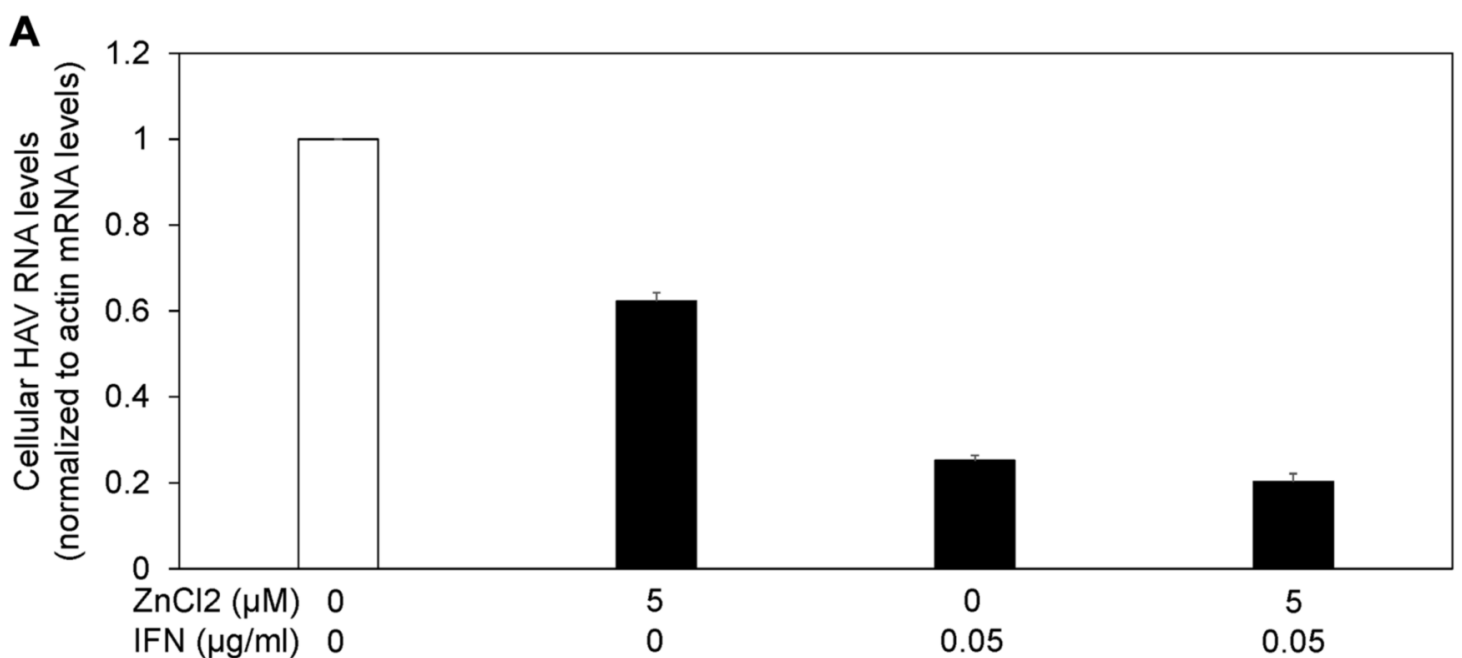

B

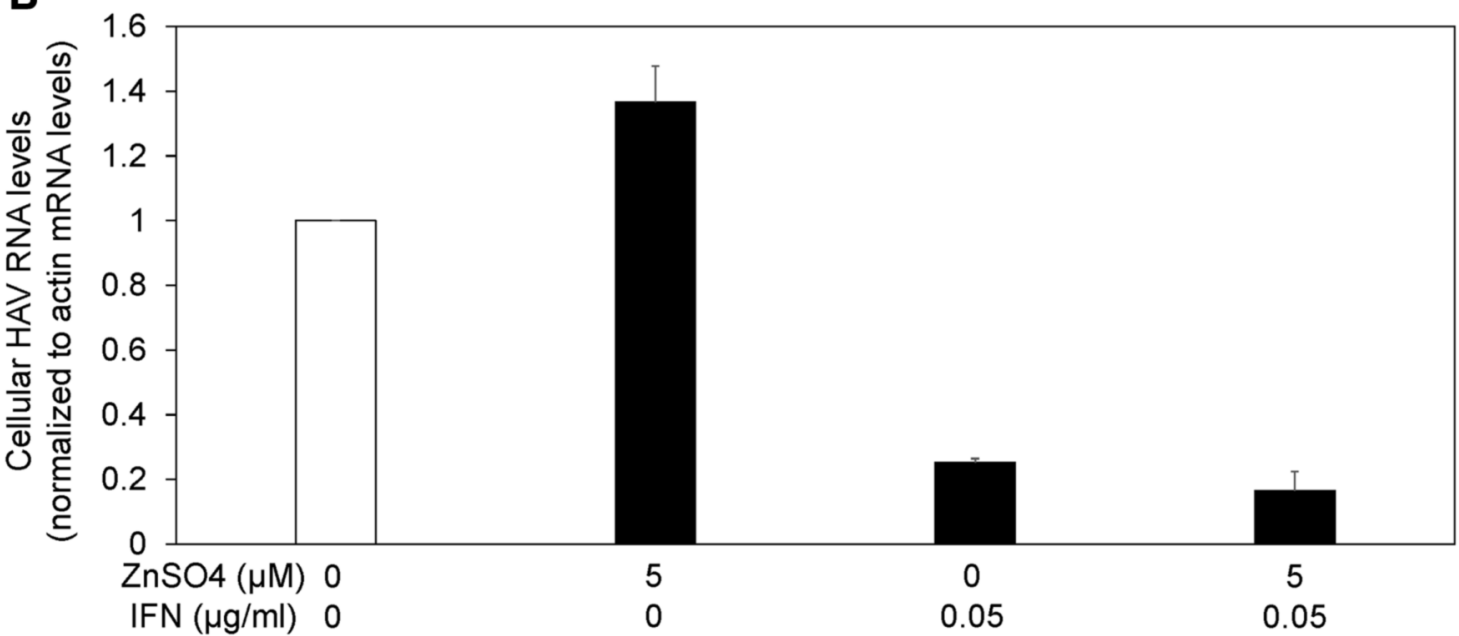

Figure 4. Zinc compounds enhanced the antiviral activity of interferon against hepatitis A virus (HAV) replication. $(A)$ Zinc chloride $\left(Z n C l_{2}\right),(B)$ zinc sulfate $\left(\mathrm{ZnSO}_{4}\right)$. Drugs were added 24 post infection with 0.01 MOI HAV genotype IIIA HA11-1299. HAV RNA was measured by real-time reverse transcription-polymerase chain reaction. IFN: Interferon. Data are expressed as means sstandard deviations of triplicate determinations from 3 independent experiments.

other positive sense RNA viruses, such as Sindbis virus, human immunodeficiency virus (HIV) and hepatitis E virus (HEV) $(13,29,30)$, and DNA viruses, such as vaccinia virus (31). Among picornaviruses, zinc chloride has been shown to inhibit the replication of rhinovirus 2 (28) and destabilize poliovirus capsid (32). Zinc chloride has also been shown to inhibit HIV reverse transcriptase and HEV RNA-dependent RNA polymerase $(\operatorname{RdRp})(13,30)$. These antiviral effects of zinc chloride may be through direct antiviral mechanisms or indirect mechanisms through the interferon system.

Wei et al. have reported that zinc compounds do not interfere with transmissible gastroenteritis virus (TGEV) cell binding but that zinc compounds mediate antiviral effects through inhibition of viral entry or egress or the intracellular phase of the viral life-cycle (33). In vitro experiments have demonstrated that $\mathrm{Zn}^{2+}$ possesses antiviral activity through inhibition of SARS-CoV-2 RNA polymerase (34). As HAV also infects humans through the fecal-oral route, zinc may prevent HAV infection (9).

In general, human blood concentration of zinc is $80-130$ $\mu \mathrm{g} / \mathrm{dl}$ and zinc and zinc acetate are prescribed at concentrations of $34 \mathrm{mg}$ daily and 150-250 mg daily, respectively, for zinc deficiency $(7,35)$. We have previously reported that 50-100 $\mu \mathrm{M}$ zinc sulfate only inhibited HAV replication in a dose-dependent manner, and 500-1000 $\mu \mathrm{M}$ zinc sulfate treatment for $48 \mathrm{~h}$ reduced viability of Huh7derived cell lines (9). In the present study, to examine the effects of zinc compounds on antiviral activities against HAV 


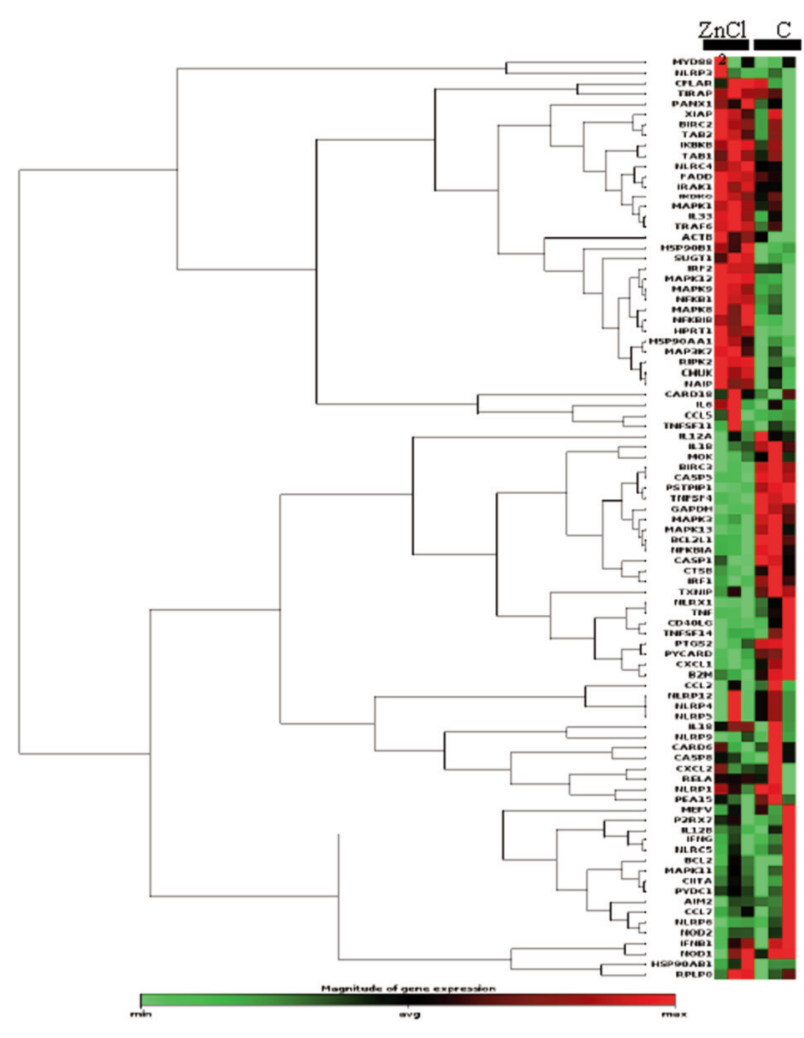

Figure 5. Clustergram of gene expression analysis of inflammasome associated signaling pathways in human hepatoma Huh7 cells treated with or without zinc chloride $\left(\mathrm{Zn} \mathrm{Cl}_{2}\right)$. C: Untreated control.

by interferon-alpha-2a, we used lower concentrations of zinc chloride or zinc sulfate at $\sim 20 \mu \mathrm{M}$ or $\sim 20 \mu \mathrm{M}$, respectively.

However, human blood concentration of interferon-alpha is $10 \mathrm{pg} / \mathrm{ml}$ and pegylated interferon-alpha-2a are prescribed at concentrations of 90-180 $\mu \mathrm{g} /$ body weekly, for chronic hepatitis B (36). In the present study, to examine the effects of zinc chloride on antiviral activities of interferon-alpha-2a against $\mathrm{HAV}$, we used $0.05 \mu \mathrm{g} / \mathrm{ml}$ interferon-alpha-2a in cell culture medium for $96 \mathrm{~h}$ (Figure 2).

We also examined the effects of $0.05 \mu \mathrm{g} / \mathrm{ml}$ interferonalpha-2a with or without $5 \mu \mathrm{M}$ zinc chloride on the replication of HAV genotype IIIA HA11-1299 after serial passages in Huh7 cells. In this experiment, we infected Huh7 cells with 0.1 MOI HAV and added the drugs at the same time. Serial passages were performed as previously described (37). After 3 serial passages, HAV RNA disappeared from Huh7 cells treated with interferon-alpha-2a alone or in combination.

It has been reported that the supernatant of Huh7-derived cell line Huh-7.5 cells infected with noncytopathic HAV HM175/p16 contain two populations of virus particles: membrane-cloaked quasi-enveloped virus (eHAV) and nonenveloped virus (38). HAV cellular receptor 1 (HAVcr-1),
Table I. Significantly changed inflammasome associated gene expressions by zinc chloride treatment of Huh7 cells infected with hepatitis A virus.

\begin{tabular}{lcc}
\hline Gene symbol & Fold regulation & $p$-Value \\
\hline MAPK12 & 2.47 & 0.000127 \\
BIRC3 & -4.34 & 0.000091 \\
IL1B & -2.08 & 0.015971 \\
PSTPIP1 & -4.22 & 0.000033 \\
PTGS2/COX2 & -4.16 & 0.001527 \\
PYCARD & -2.10 & 0.003330 \\
TNF & -3.95 & 0.045568
\end{tabular}

MAPK12: Mitogen-activated protein kinase 12; BIRC3: baculoviral IAP repeat containing 3; IL1B: interleukin 1 beta; PSTPIP1: proline-serinethreonine phosphatase interacting protein 1; PTGS2: prostaglandinendoperoxide synthase 2; PYCARD: PYD and CARD domain containing; TNF: tumor necrosis factor. Gene expression changes were considered statistically significant at $p<0.05$ and the difference of gene expression was more than 2-fold. Each experiment was performed at least in triplicate.

integrin $\beta$ and gangliosides have been candidates as HAV cell surface or endosomal receptors $(39,40)$. One of the limitations of our study is that we did not examine the effect of zinc chloride on HAV RNA levels in conditioned medium. Further studies are needed in this regard. The other limitation of our study is that FCS contained zinc in the present study although we used zinc-free medium.

Interferon and broad-spectrum non-specific antiviral agents have been shown to be effective for the inhibition of HAV replication (14). In this study, we showed that zinc chloride inhibited HAV replication and enhanced the antiviral activity induced by interferon. Zinc chloride may affect the inflammasome-associated signaling pathway in hepatocytes. Further studies are needed in order to explore the effect of zinc chloride on inflammasome-associated signaling.

\section{Conflicts of Interest}

No competing interests exist in relation to this study.

\section{Authors' Contributions}

T.K., R.S. and R.M. designed, and T.K. and R.S. performed the experiments, analyzed data and performed statistical analyses. H.T, F.M, N.M., H.O. and M.M. commented on the article. T.K. and R.S. conceived the study. T.K., R.S. and R.M. wrote the article. All Authors read and approved the final article.

\section{Acknowledgements}

This work was supported by the Japan Agency for Medical Research and Development (AMED) under Grant Numbers JP19fk0210043 (T.K., H.O.) and JP20fk0210075 (T.K.). 


\section{References}

1 Abutaleb A and Kottilil S: Hepatitis A: Epidemiology, natural history, unusual clinical manifestations, and prevention. Gastroenterol Clin North Am 49(2): 191-199, 2020. PMID: 32389358. DOI: $10.1016 /$ j.gtc 2020.01 .002

2 Khounvisith V, Xaiyaphet X, Chanthavilay P, Nouanthong P, Vongphachanh B, Reinharz D, Muller CP and Black AP: Hepatitis A virus in Lao People's Democratic Republic: Seroprevalence and risk factors. Am J Trop Med Hyg 103(1): 164-168, 2020. PMID: 32342836. DOI: 10.4269/ajtmh.19-0451

3 Gallian P, Barlet V, Mouna L, Gross S, Morel P, Le Cam S, Ricard C, Maugard C, Pouchol E, Flan B, Visse C, Djoudi R, Figoni J, De Valk H, Tiberghien P and Roque-Afonso AM: Persisting higher prevalence of hepatitis A virus RNA in blood donors, France, 2018. Euro Surveill 24(47): 1900685, 2019. PMID: 31771700. DOI: 10.2807/1560-7917.ES.2019.24.47.1900695

4 Koga M, Lim LA, Ogishi M, Satoh H, Kikuchi T, Adachi E, Sugiyama R, Kiyohara T, Suzuki R, Muramatsu M, Koibuchi T, Tsutsumi $\mathrm{T}$ and Yotsuyanagi $\mathrm{H}$ : Comparison of the clinical features of hepatitis A in people living with HIV between pandemics in 1999-2000 and 2017-2018 in the Metropolitan area of Japan. Jpn J Infect Dis 73(2): 89-95, 2020. PMID: 31666497. DOI: 10.7883 /yoken.JJID.2019.275

5 Lal BB, Sood V, Snehavardhan P, Khanna R, Pasupuleti SSR, Siloliya M, Kumar G and Alam S: A novel, bedside, etiology specific prognostic model (Peds-HAV) in Hepatitis A induced pediatric acute liver failure. Hepatol Int 4(4): 483-490, 2020. PMID: 32372333. DOI: 10.1007/s12072-020-10050-0

6 Aggarwal R and Goel A: Hepatitis A: Epidemiology in resourcepoor countries. Curr Opin Infect Dis 28(5): 488-496, 2015. PMID: 26203853. DOI: 10.1097/QCO.0000000000000188

7 Kodama H, Tanaka M, Naito Y, Katayama K and Moriyama M: Japan's practical guidelines for zinc deficiency with a particular focus on taste disorders, inflammatory bowel disease, and liver cirrhosis. Int J Mol Sci 21(8): 2941, 2020. PMID: 32331308. DOI: $10.3390 /$ ijms 21082941

8 Read SA, Obeid S, Ahlenstiel C and Ahlenstiel G: The role of zinc in antiviral immunity. Adv Nutr 10(4): 696-710, 2019. PMID: 31305906. DOI: 10.1093/advances/nmz013

9 Ogawa M, Kanda T, Suganami A, Nakamoto S, Win NN, Tamura Y, Nakamura M, Matsuoka S, Yokosuka O, Kato N, Ohara O, Okamoto H, Moriyama M and Shirasawa H: Antiviral activity of zinc sulfate against hepatitis A virus replication. Future Virol 14(6): 399-406, 2019. DOI: 10.2217/fvl-2019-0031

10 Nagamine T, Nakajima K, Takada H, Sekine Y and Suzuki K: Induction of type 1 interferon receptor by zinc in U937 cells. Cytokine 46(3): 346-350, 2009. PMID: 19362011. DOI: 10.1016/j.cyto.2009.03.005

11 Jiang X, Kanda T, Wu S, Nakamoto S, Saito K, Shirasawa H, Kiyohara T, Ishii K, Wakita T, Okamoto H and Yokosuka O: Suppression of La antigen exerts potential antiviral effects against hepatitis A virus. PLoS One 9(7): e101993, 2014. PMID: 24999657. DOI: 10.1371/journal.pone.0101993

$12 \mathrm{Wu} \mathrm{S}$, Kanda T, Imazeki F, Nakamoto S, Tanaka T, Arai M, Roger T, Shirasawa H, Nomura F and Yokosuka O: Hepatitis B virus e antigen physically associates with receptor-interacting serine/threonine protein kinase 2 and regulates IL-6 gene expression. J Infect Dis 206(3): 415-420, 2012. PMID: 22615316. DOI: $10.1093 /$ infdis/jis363
13 Kaushik N, Subramani C, Anang S, Muthumohan R, Shalimar, Nayak B, Ranjith-Kumar CT and Surjit M: Zinc salts block Hepatitis E virus replication by inhibiting the activity of viral RNA-dependent RNA polymerase. J Virol 91(21): e00754-17, 2017. PMID: 28814517. DOI: 10.1128/JVI.00754-17

14 Yang L, Kiyohara T, Kanda T, Imazeki F, Fujiwara K, GaussMüller V, Ishii K, Wakita T and Yokosuka O: Inhibitory effects on HAV IRES-mediated translation and replication by a combination of amantadine and interferon-alpha. Virol J 7: 212, 2010. PMID: 20815893. DOI: 10.1186/1743-422X-7-212

15 Kanda T, Sasaki R, Masuzaki R, Takahashi H, Mizutani T, Matsumoto N, Nirei K and Moriyama M: Co-occurrence of hepatitis A infection and chronic liver disease. Int J Mol Sci 21(17): 6384, 2020. DOI: 10.3390/ijms21176384

16 Feng $\mathrm{Z}$ and Lemon SM: Innate immunity to enteric hepatitis viruses. Cold Spring Harb Perspect Med 9(3): a033464, 2019. PMID: 29686040. DOI: 10.1101/cshperspect.a033464

17 Angelini G, Castagneto Gissey L, Del Corpo G, Giordano C, Cerbelli B, Severino A, Manco M, Basso N, Birkenfeld AL, Bornstein SR, Genco A, Mingrone G and Casella G: New insight into the mechanisms of ectopic fat deposition improvement after bariatric surgery. Sci Rep 9(1): 17315, 2019. PMID: 31754142. DOI: 10.1038/s41598-019-53702-4

18 Dash S, Aydin Y and Moroz K: Chaperone-mediated autophagy in the liver: Good or bad? Cells 8(11): 1308, 2019. PMID: 31652893. DOI: $10.3390 /$ cells8111308

19 You Y, Li WZ, Zhang S, Hu B, Li YX, Li HD, Tang HH, Li QW, Guan YY, Liu LX, Bao WL and Shen X: SNX10 mediates alcoholinduced liver injury and steatosis by regulating the activation of chaperone-mediated autophagy. J Hepatol 69(1): 129-141, 2018. PMID: 29452206. DOI: 10.1016/j.jhep.2018.01.038

20 Polotsky YE, Vassell RA, Binn LN and Asher LV: Immunohistochemical detection of cytokines in tissues of Aotus monkeys infected with hepatitis A virus. Ann N Y Acad Sci 730: 318-321, 2019. PMID: 8080199. DOI: 10.1111/j.1749-6632.1994.tb4 4279.x

21 Locarnini S: A virological perspective on the need for vaccination. J Viral Hepat 7 (Suppl 1): 5-6, 2000. PMID: 10866836. DOI: 10.1046/j.1365-2893.2000.00020.x

22 Choi YS, Jung MK, Lee J, Choi SJ, Choi SH, Lee HW, Lee JJ, Kim HJ, Ahn SH, Lee DH, Kim W, Park SH, Huh JR, Kim HP, Park JY and Shin EC: Tumor necrosis factor-producing Tregulatory cells are associated with severe liver injury in patients with acute hepatitis A. Gastroenterology 154(4): 1047-1060, 2018. PMID: 29229400. DOI: 10.1053/j.gastro.2017.11.277

23 Somerville TDD, Xu Y, Wu XS, Maia-Silva D, Hur SK, de Almeida LMN, Preall JB, Koo PK and Vakoc CR: ZBED2 is an antagonist of interferon regulatory factor 1 and modifies cell identity in pancreatic cancer. Proc Natl Acad Sci USA 117(21): 11471-11482, 2020. PMID: 32385160. DOI: 10.1073/pnas. 1921484117

24 Salzberg S, Hyman T, Turm H, Kinar Y, Schwartz Y, Nir U, Lejbkowicz $\mathrm{F}$ and Huberman E: Ectopic expression of 2-5A synthetase in myeloid cells induces growth arrest and facilitates the appearance of a myeloid differentiation marker. Cancer Res 57(13): 2732-2740, 1997. PMID: 9205084.

25 Kronfeld-Kinar Y, Vilchik S, Hyman T, Leibkowicz F and Salzberg S: Involvement of PKR in the regulation of myogenesis. Cell Growth Differ 10(3): 201-212, 1999. PMID: 10099834. 
26 Van Molle W, Van Roy M, Van Bogaert T, Dejager L, Van Lint P, Vanlaere I, Sekikawa K, Kollias G and Libert C: Protection of zinc against tumor necrosis factor induced lethal inflammation depends on heat shock protein 70 and allows safe antitumor therapy. Cancer Res 67(15): 7301-7307, 2007. PMID: 17671199. DOI: 10.1158/0008-5472.CAN-06-4010

27 Poleganov MA, Pfeilschifter J and Mühl H: Expanding extracellular zinc beyond levels reflecting the albumin-bound plasma zinc pool potentiates the capability of IL-1beta, IL-18, and IL-12 to act as IFN-gamma-inducing factors on PBMC. J Interferon Cytokine Res 27(12): 997-1001, 2007. PMID: 18184040. DOI: 10.1089/jir.2007.0037

28 Merluzzi VJ, Cipriano D, McNeil D, Fuchs V, Supeau C, Rosenthal AS and Skiles JW: Evaluation of zinc complexes on the replication of rhinovirus 2 in vitro. Res Commun Chem Pathol Pharmacol 66(3): 425-440, 1989. PMID: 2558406.

29 Bracha $M$ and Schlesinger MJ: Inhibition of sindbis virus replication by zinc ions. Virology 72(1): 272-277, 1976. PMID: 945640. DOI: 10.1016/0042-6822(76)90330-5

30 Fenstermacher KJ and DeStefano JJ: Mechanism of HIV reverse transcriptase inhibition by zinc: formation of a highly stable enzyme-(Primer-Template) complex with profoundly diminished catalytic activity. J Biol Chem 286(47): 40433-40442, 2011. PMID: 21953456. DOI: 10.1074/jbc.M111.289850

31 Katz E and Margalith E: Inhibition of vaccinia virus maturation by zinc chloride. Antimicrob Agents Chemother 19(2): 213-217, 1981. PMID: 7347557. DOI: 10.1128/aac.19.2.213

32 Ratka M, Lackmann M, Ueckermann C, Karlins U and Koch G: Poliovirus-associated protein kinase: destabilization of the virus capsid and stimulation of the phosphorylation reaction by $\mathrm{Zn}^{2+}$. J Virol 63(9): 3954-3960, 1989. PMID: 2548009.

33 Wei Z, Burwinkel M, Palissa C, Ephraim E and Schmidt MF: Antiviral activity of zinc salts against transmissible gastroenteritis virus in vitro. Vet Microbiol 160(3-4): 468-472, 2012. PMID: 22818659. DOI: 10.1016/j.vetmic.2012.06.019

34 Skalny AV, Rink L, Ajsuvakova OP, Aschner M, Gritsenko VA, Alekseenko SI, Svistunov AA, Petrakis D, Spandidos DA, Aaseth J, Tsatsakis A and Tinkov AA: Zinc and respiratory tract infections: perspectives for COVID-19 (Review). Int J Mol Med 46(1): 1726, 2020. PMID: 32319538. DOI: 10.3892/ijmm.2020.4575
35 Moriyama M, Matsumura H, Fukushima A, Ohkido K, Arakawa Y, Nirei K, Yamagami H, Kaneko M, Tanaka N and Arakawa Y: Clinical significance of evaluation of serum zinc concentrations in C-viral chronic liver disease. Dig Dis Sci 51(11): 1967-1977, 2006. PMID: 17048113. DOI: 10.1007/s10620-005-9051-7

36 Matsumoto A, Nishiguchi S, Enomoto H, Tanaka Y, Shinkai N, Okuse C, Kang JH, Matsui T, Miyase S, Yatsuhashi H, Nagaoka S, Kanda T, Enomoto M, Yamada R, Hiramatsu N, Saito S, Takaguchi K, Ito K, Masaki T, Morihara D, Tsuge M, Chayama K, Ikeda F, Kagawa T, Kondo Y, Murata K and Tanaka E: Pilot study of tenofovir disoproxil fumarate and pegylated interferonalpha 2a add-on therapy in Japanese patients with chronic hepatitis B. J Gastroenterol, 2020. PMID: 32666202. DOI: 10.1007/s00535-020-01707-6

37 Ait-Goughoulte M, Kanda T, Meyer K, Ryerse JS, Ray RB and Ray R: Hepatitis C virus genotype 1a growth and induction of autophagy. J Virol 82(5): 2241-2249, 2008. PMID: 18077704. DOI: $10.1128 /$ JVI.02093-07

38 Feng Z, Hensley L, McKnight KL, Hu F, Madden V, Ping L, Jeong SH, Walker C, Lanford RE and Lemon SM: A pathogenic picornavirus acquires an envelope by hijacking cellular membranes. Nature 496(7445): 367-371, 2013. PMID: 23542590. DOI: 10.1038/nature12029

39 Das A, Barrientos R, Shiota T, Madigan V, Misumi I, McKnight KL, Sun L, Li Z, Meganck RM, Li Y, Kaluzna E, Asokan A, Whitmire JK, Kapustina M, Zhang Q and Lemon SM: Gangliosides are essential endosomal receptors for quasienveloped and naked hepatitis A virus. Nat Microbiol 5(9): 1069-1078, 2020. PMID: 32451473. DOI: 10.1038/s41564-0200727-8

40 Kanda T, Sasaki R, Masuzaki R, Matsumoto N, Ogawa M and Moriyama M: Cell culture systems and drug targets for hepatitis A virus infection. Viruses 12(5): 533, 2020. PMID: 32408660. DOI: $10.3390 / \mathrm{v} 12050533$

Received September 5, 2020

Revised September 10, 2020

Accepted September 11, 2020 